\title{
Diabetes, perioperative ischaemia and volatile anaesthetics: consequences of derangements in myocardial substrate metabolism
}

\author{
Charissa E van den Brom ${ }^{1,2^{*}}$, Carolien SE Bulte ${ }^{1}$, Stephan A Loer ${ }^{1}$, R Arthur Bouwman ${ }^{1}$ and Christa Boer ${ }^{1}$
}

\begin{abstract}
Volatile anaesthetics exert protective effects on the heart against perioperative ischaemic injury. However, there is growing evidence that these cardioprotective properties are reduced in case of type 2 diabetes mellitus. A strong predictor of postoperative cardiac function is myocardial substrate metabolism. In the type 2 diabetic heart, substrate metabolism is shifted from glucose utilisation to fatty acid oxidation, resulting in metabolic inflexibility and cardiac dysfunction. The ischaemic heart also loses its metabolic flexibility and can switch to glucose or fatty acid oxidation as its preferential state, which may deteriorate cardiac function even further in case of type 2 diabetes mellitus.

Recent experimental studies suggest that the cardioprotective properties of volatile anaesthetics partly rely on changing myocardial substrate metabolism. Interventions that target at restoration of metabolic derangements, like lifestyle and pharmacological interventions, may therefore be an interesting candidate to reduce perioperative complications. This review will focus on the current knowledge regarding myocardial substrate metabolism during volatile anaesthesia in the obese and type 2 diabetic heart during perioperative ischaemia.
\end{abstract}

Keywords: Volatile anaesthetics, Substrate metabolism, Ischaemia, Diabetes, Heart

\section{Introduction}

Perioperative cardiac complications occur in $2-5 \%$ of all non-cardiac surgical procedures, which globally affect 5-12 million patients each year [1]. More specifically, $0.65 \%$ of these patients develop perioperative myocardial infarction or cardiac arrest [2]. Perioperative cardiac complications are an economical, medical and social burden that warrants optimisation of perioperative health and cardiovascular care to improve patient outcome and reduce health care costs. There are several well-known predictors for perioperative cardiac complications identified, such as type of surgery, ASA classification and increasing age [1,2]. Additionally, lifestyle risk factors associated with metabolic alterations, such as excessive dietary intake and physical inactivity, are strongly associated with clinical risk factors that predict perioperative cardiovascular complications [1].

\footnotetext{
* Correspondence: c.vandenbrom@vumc.nl

'Department of Anesthesiology, Experimental Laboratory for VItal Signs

(ELVIS), VU University Medical Center, De Boelelaan 1117, 1081 HV, Amsterdam, the Netherlands

2Laboratory for Physiology, VU University Medical Center, Van der Boechorststraat 7, 1081 BT, Amsterdam, the Netherlands
}

Lifestyle risk factors related to obesity and type 2 diabetes mellitus (T2DM) have become an epidemic over the last decade. Worldwide, 366 million people have T2DM [3]. It is predicted that in the year 2030 about 552 million people will have overt diabetes, mainly T2DM [3]. Patients with T2DM are more likely to develop coronary artery disease and myocardial ischaemia [4] and have an increased cardiovascular complication rate after major non-cardiac surgery [5].

In addition to prevention programs to reduce the burden of metabolic disease on the perioperative process, there are intraoperative cardioprotective strategies available that may reduce the impact of ischaemic injury during and after surgery, like the application of the volatile anaesthetics sevoflurane and isoflurane. These volatile anaesthetics exert multiple protective effects that enhance perioperative preservation of the heart in patients [6] and rats [7]. Although exposure to volatile anaesthetics reduced infarct size and improved post-ischaemic recovery in healthy rats [7], the cardioprotective effects of these agents are reduced in obese [8] and hyperglycaemic [9]

\section{Biomed Central}


rats. Derangements in myocardial substrate metabolism are one of the hypothetical mechanisms that may explain the suppressed cardioprotective capacity in T2DM [10-12]. It is however not yet understood how these myocardial metabolic alterations affect intraoperative cardioprotective mechanisms.

In order to elucidate the impact of altered myocardial substrate metabolism on intraoperative myocardial protection, this review will focus on available preclinical knowledge regarding myocardial substrate metabolism during volatile anaesthesia in the obese/T2DM heart under normal conditions and in the context of ischaemia. We first describe myocardial substrate metabolism under healthy, obese/T2DM and ischaemic conditions, followed by an overview of the interaction between substrate metabolism and volatile anaesthetics in the context of perioperative ischaemia and reperfusion injury. Finally, we propose strategies to modulate myocardial substrate metabolism that may contribute to an improvement of myocardial protective capacity and perioperative and postoperative outcome in obesity and T2DM.

\section{Myocardial substrate metabolism}

Fatty acids and carbohydrates are essential for the pump function of the heart [13]. Under physiological conditions, myocardial contractile function relies on oxidation of fatty acids (60-70\%), glucose (30-40\%) and to a lesser extent lactate, ketones, amino acids and pyruvate (10\%) to generate adenosine triphosphate (ATP) [14-16]. The heart exerts a metabolic flexibility, and myocardial substrate utilisation depends on substrate availability, nutritional status, and exercise level. With glucose as the more energetically efficient substrate, the healthy heart is able to switch to glucose under conditions of stress, such as ischaemia, pressure overload or in heart failure.

Glucose metabolism is regulated through multiple steps, including uptake, glycolysis and pyruvate decarboxylation. Myocardial glucose supply is regulated 1) via circulating glucose levels or 2) by release of glucose from intracellular glycogen stores [17]. Myocardial glucose uptake depends on the sarcolemmal glucose transporter GLUT1 (insulin-independent) and the dominant glucose transporter GLUT4 (insulin-dependent) (Figure 1) [18]. After uptake, glucose is broken down into pyruvate by glycolysis, consumed by the mitochondria and decarboxylated into acetyl-CoA by pyruvate dehydrogenase. AcetylCoA enters the tricarboxylic acid cycle with entry of reducing equivalents to the electron transport chain and oxidative phosphorylation, which finally leads to ATP formation (Figure 1).

Fatty acid metabolism consists of uptake, oxidation and esterification. There are two sources of fatty acids for myocardial metabolism: 1) circulating albumin bound fatty acids derived from adipose tissue via lipolysis or 2) released from triglyceride-rich lipoproteins from the liver [19]. Fatty acids enter cardiomyocytes by simple diffusion and via transport through three different membrane fatty acid transporters - fatty acid translocase (FAT)/CD36, fatty acid transport protein (FATP1/6) and plasma membrane fatty acid binding protein (FABPpm) (Figure 1) [19]. After sarcolemmal uptake, intracellular fatty acids are activated to form fatty acyl-CoA, which can undergo beta-oxidation or esterification to form intracellular triglycerides [20]. Fatty acid oxidation requires fatty acyl-CoA entry into the mitochondria, which is dependent on the activity of carnitine palmitoyl transferase (CPT-1) [21]. After translocation into the mitochondria, fatty acyl-CoA can enter the beta-oxidation pathway to form acetyl-CoA and subsequently ATP (Figure 1). Under physiological conditions, $70-90 \%$ of the fatty acids that enter cardiomyocytes are oxidised for ATP generation, whereas $10-30 \%$ is converted to triglycerides by lipoprotein lipase [22]. In case of energy expenditure, intracellular triglyceride stores can be hydrolysed as an endogenous fatty acid source, which is explanatory for $10 \%$ of the total fatty acid utilisation in the heart [23].

\section{Type 2 diabetes mellitus}

Alterations in myocardial substrate metabolism in T2DM hearts are extensively reviewed by others [15,22,24]. In short, myocardial fatty acid metabolism is initially enhanced in T2DM hearts, with increased rates of fatty acid oxidation and esterification $[25,26]$. There are two proposed mechanisms that may underlie this derangement: 1) increased fatty acid uptake due to increased substrate supply and augmented expression and localisation of sarcolemmal fatty acid transporters [26] and 2) increased oxidation and esterification due to changes in regulation at both the enzymatic and transcriptional level [26].

In addition, a decreased myocardial glucose metabolism is a concomitant feature of the T2DM heart [25,26]. The slow rate of glucose transport across the sarcolemmal membrane due to decreased glucose transporters leads to a restriction of glucose oxidation. Accordingly, fatty acid oxidation has an inhibitory effect on the pyruvate dehydrogenase complex due to increased fatty acid supply. Taken together, the T2DM heart has a distinct metabolic phenotype, characterised by enhanced myocardial fatty acid metabolism and a concomitant reduction in myocardial glucose metabolism.

\section{Ischaemia}

Myocardial ischaemia occurs when coronary perfusion is inadequate to maintain a sufficient oxygen supply/demand ratio. Ischaemia influences both myocardial substrate metabolism and myocardial function. The pathophysiological mechanisms underlying this phenomenon have been reviewed previously [24,27]. 


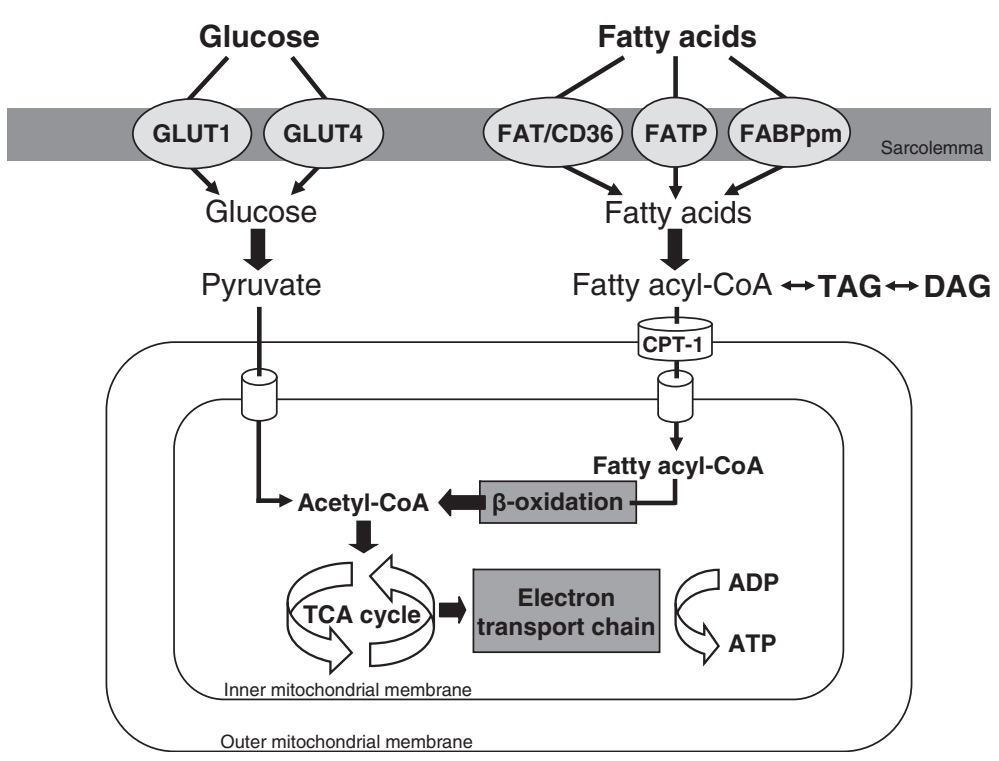

Figure 1 Glucose and fatty acid metabolism in the cardiomyocyte. Glucose uptake into the cell occurs through the glucose transporters GLUT1 and GLUT4. Once inside, glucose is broken down into pyruvate by glycolysis. Pyruvate is subsequently transported into the mitochondria and decarboxylated to acetyl-CoA. Non-esterified fatty acids are taken up through fatty acid transporter (FAT)/CD36, fatty acid transport protein (FATP) and plasma membrane fatty acid binding protein (FABPpm). Intracellular fatty acids form fatty acyl-CoA and can either be esterified into triglycerides (TG) or enter the mitochondria via carnitine palmitoyl transferase (CPT-1). Fatty acyl-CoA enters the $\beta$-oxidation pathway, forming acetyl-CoA. Glucose or fatty acid-derived acetyl-CoA enters the tricarboxylic acid (TCA) cycle with entry of reducing equivalents to the electron transport chain and oxidative phosphorylation, and finally ATP is formed.

In the event of ischaemia, high-energy phosphates are depleted, ionic homeostasis is disturbed and contractile dysfunction is caused. The energetic demand of the heart changes in case of myocardial ischaemia. The heart usually responds to injury by increasing myocardial glucose metabolism to improve its energetic efficiency $[22,24]$. However, increased adipose tissue lipolysis results in increased plasma free fatty acid concentrations, which may increase myocardial fatty acid utilisation and esterification [27]. In this context, glycolysis becomes an important source of energy due to its ATP-generating ability in the absence of oxygen. It is also suggested that in the early phase of ischaemia, fatty acid oxidation shifts to the more efficient glucose oxidation, followed by a decrease in total substrate oxidation [24]. Increased glycolysis can parallel depression of myocardial glucose and fatty acid oxidation depending on the severity of ischaemia. Overall, the ischaemic heart favours the energetically more efficient glucose (3.17 ATP/oxygen molecule) over fatty acid oxidation (2.83 ATP/oxygen molecule) [28]. This flexibility additionally depends on substrate availability, oxygen supply, tissue vascularisation and myocardial workload. In conclusion, the metabolic state of the ischaemic heart is characterised by imbalances in substrate availability and utilisation and is also influenced the severity of ischaemia.
The combination of type 2 diabetes mellitus and ischaemia The cardiometabolic profile of patients with T2DM makes them more prone to develop plaque formation and intravascular stenosis, leading to the development of stroke or myocardial infarction. In addition, these patients are more susceptible to subsequent episodes of ischaemia $[29,30]$. Whereas the metabolic undisturbed heart usually responds to injury by increasing myocardial glucose metabolism [22,24], this adaptive response is inhibited by insulin resistance, which is a characteristic of obesity and T2DM. This inhibition results in increased myocardial fatty acid metabolism [31,32], increased oxygen consumption, decreased cardiac efficiency [31] and altered myocardial perfusion [33]. In obese or T2DM animals subjected to myocardial ischaemia the findings are inconclusive. It has been shown that obesity reduced ischaemia and reperfusion injury [34] and myocardial function during ischaemia (and reperfusion) [35-40], but also similar ischaemia and reperfusion injury was found [41]. Additionally, increased glucose oxidation and decreased fatty acid oxidation after myocardial infarction was found, which was ameliorated in obese rats [40]. Obese rats with insulin resistance resulted in preserved myocardial function [36] or aggravated [36,42-44] ischaemia and reperfusion injury. Moreover, the combination of insulin resistance, dyslipidaemia and hypertension in obese 
animals seems to increase the susceptibility of the heart to ischaemia (and reperfusion) injury [45-48]. Others however reported that myocardial injury during ischaemia was unaffected in T2DM rats, independent of the severity of T2DM [49]. In case of genetically induced T2DM rats in combination with a high cholesterol diet, ischaemic injury was however exacerbated [50]. As stated earlier, these inconclusive results in animal experiments suggest that the type and severity of T2DM may influence the sensitivity of the heart to ischaemic insults.

With regard to myocardial substrate metabolism, endogenous glycogen stores may support increased glucose availability as substrate for the heart, and may thus be beneficial in case of ischaemic injury. However, whether pre-ischaemic glycogen levels are beneficial or detrimental depends on the duration of T2DM [51] and to the extent of glycogen depletion during ischaemia [52].

Overall, the effects of imbalanced myocardial substrate metabolism during ischaemia in T2DM are inconclusive. These observed contrasts may be due to differences in the severity of ischaemia, the measured outcome parameter, exogenous circumstances and the severity of the experimental model for T2DM [32,53].

\section{Effects of volatile anaesthetics in animals Cardioprotective effects during ischaemia}

Sevoflurane and isoflurane are commonly used volatile anaesthetics. Sevoflurane and isoflurane make the rat heart more resistant to ischaemia and reperfusion injury [54-58]. It has been shown that proteins related to myocardial substrate metabolism are, amongst others, affected by sevoflurane-induced cardioprotection. PI3K and Akt, which regulate translocation of glucose transporter 4 (GLUT4) to the sarcolemma for glucose uptake, are increased during sevoflurane in the isolated ischaemic rat heart [59]. Moreover, sevoflurane enhances GLUT4 expression in lipid rafts, increases glucose oxidation and decreases fatty acid oxidation after ischaemia and reperfusion injury in isolated working rat hearts compared to untreated ischaemic hearts [10]. In the same study, no alterations in AMP activated protein kinase (AMPK) phosphorylation, pyruvate dehydrogenase activity and glycogen content were found, whereas sevoflurane decreased triglycerides and ceramide levels after ischaemia and reperfusion injury [10].

Moreover, volatile anaesthetics are also known to alter mitochondrial function, which is nicely reviewed by Stadnicka et al. [60]. In short, it has been shown that sevoflurane and isoflurane open mitochondrial ATPactivated potassium (mito $\mathrm{K}_{\mathrm{ATP}}$ ) channels $[61,62]$, activates reactive oxygen species [62] and thereby alters mitochondrial metabolism [63].

Together, these results suggest a role for myocardial substrate metabolism in the cardioprotective effects of volatile anaesthesia during ischaemia and reperfusion injury in animals, although evidence is limited.

\section{Myocardial substrate metabolism during volatile anaesthesia}

In rats, it has been shown that in vivo myocardial glucose uptake was increased in the heart during isoflurane (2 vol\%) when compared to sevoflurane (3.5 vol\%) [64]. An explanation could be the differences by more stable blood glucose levels during sevoflurane. However, a limitation of this study was that the effects were not compared with findings in awake rats or using non-volatile anaesthetics. Others found that isoflurane (2 vol\%) increased myocardial glucose uptake compared to awake mice [65].

The effects of sevoflurane on myocardial substrate metabolism have only been studied ex vivo. Sevoflurane (2 vol\%) decreased FAT/CD36 in lipid rafts and fatty acid oxidation in isolated rat hearts [12]. And, although studied in skeletal muscle cells, sevoflurane (2.6-5.2\%) increased glucose uptake [66]. Altogether, these results suggest that isoflurane and sevoflurane might switch myocardial metabolism to glucose as energetically more efficient substrate.

Volatile anaesthesia is also known to affect pancreatic insulin release. In isolated rat pancreatic islets, enflurane [67] and isoflurane [68] have an inhibitory effect on glucose-stimulated insulin release. In rats, isoflurane impaired glucose-induced insulin release [69], whereas sevoflurane impaired glucose tolerance [70], which both resulted in hyperglycaemia. Therefore it seems that impaired insulin release during volatile anaesthesia might have a negative effect on substrate metabolism. However, the beneficial cardioprotective effects may outweigh the adverse effects of impaired insulin secretion, as the American Heart Association 2007 guidelines on 'perioperative cardiovascular evaluation and care for non cardiac surgery' suggested that it can be beneficial to use volatile anaesthetics during non cardiac surgery for maintenance of general anaesthesia in haemodynamically stable patients at risk for myocardial ischaemia [1].

\section{Alterations in cardioprotective mechanisms in the metabolic altered heart}

The healthy heart is capable of protecting itself against stressors like ischaemia by the flexibility to switch between circulating substrates. These cardioprotective properties might be enlarged during volatile anaesthesia. On the other hand, the obese/T2DM heart is less capable of switching between circulating substrates, which may contribute to a reduced intrinsic protective capacity. It is generally acknowledged that the incidence of perioperative cardiovascular complications is increased in patients with T2DM after non-cardiac surgery [5]. Accordingly, blood glucose concentrations at admission correlated 
with long-term mortality in diabetic patients with acute myocardial infarction [71], suggesting that T2DM may affect perioperative cardiovascular risk. The next paragraphs focus on available experimental knowledge whether obesity, insulin resistance, hyperlipidaemia and hyperglycaemia, important hallmarks of T2DM, exert a cumulative effect on endogenous and exogenous cardioprotective mechanisms.

\section{Obesity and insulin resistance}

It has been shown that obesity and insulin resistance inhibit the cardioprotective effects of ischaemic pre- [72] and postconditioning [73]. In high fat diet-induced obese rats, sevoflurane preconditioning failed to induce cardioprotection during myocardial ischemia and reperfusion injury [41]. Moreover, sevoflurane postconditioning did not protect the heart against myocardial and reperfusion injury in obese and insulin resistant Zucker rats [8], however, more research is necessary to draw a conclusion.

\section{Hyperlipidaemia}

The hyperlipidaemic heart has difficulties to adapt to stressors like ischaemia, suggesting that cardioprotective mechanisms are impaired. In rats it has been shown that pacing-induced cardioprotection [74] and ischaemicinduced preconditioning [75] was inhibited by hypercholesterolaemia. Sevoflurane preconditioning reduced myocardial infarct size in normocholesterolaemic rats, which was blocked in hypercholesterolaemic rats [76]. Further research is warranted to study the impact of hyperlipidaemia on anaesthesia-induced cardioprotection.

\section{Acute hyperglycaemia}

Hyperglycaemia is an independent predictor of cardiovascular risk [71]. The glycometabolic state upon hospital admission is associated with the mortality risk in T2DM patients with acute myocardial infarction [77]. It has further been shown that hyperglycaemia inhibits the cardioprotective capacity during desflurane-induced preconditioning [78], isoflurane-induced preconditioning $[9,79]$ and sevoflurane-induced postconditioning in the experimental setting [80]. Accordingly, infarct size was directly related to the severity of hyperglycaemia $[81,82]$, whereas the inhibited cardioprotective effects of isofluraneinduced preconditioning are concentration dependent and related to the severity of acute hyperglycaemia [9]. Moreover, it has been shown that hyperglycaemia attenuated cardioprotection via inhibition of Akt and endothelial nitric oxide synthase (eNOS) phosphorylation [83]. However, interpretation of abovementioned findings in relation to T2DM is difficult, because experiments were performed during acute hyperglycaemia in otherwise healthy animals without the typical characteristics of T2DM, such as obesity and insulin resistance.

\section{Type 2 diabetes mellitus}

T2DM hinders the cardioprotective effects of ischaemic preconditioning [84], which has been reviewed by Miki et al. [85]. However, the diabetic rat heart may still benefit when the preconditioning stimulus is enlarged [86]. The effects of anaesthesia-induced cardioprotection in T2DM have however never been studied. In type 1 diabetes, the protective effects of isoflurane-induced preconditioning were inhibited in case of low isoflurane concentrations, but not at high concentrations [82]. Further, sevoflurane-induced postconditioning in the type 1 diabetic heart was disturbed, whereas insulin treatment to reach normoglycaemia did not restore the cardioprotective capacity [87]. Mechanisms that are suggested to be involved include the inhibition of PI3K/Akt [86,87] and inactivity of mito $K_{\text {ATP }}^{+}$[87]. Furthermore, AMPK activation during ischaemia protects the non-obese T2DM Goto-Kakizaki rat heart against reperfusion injury [88], suggesting a role for AMPK in the cardioprotective properties of the diabetic heart. A limitation of the above-described studies is that anaesthesia-induced cardioprotection is only studied in type 1 diabetes with insulinopenia and hyperglycaemia, but without characteristics such as obesity, insulin resistance and hyperinsulinaemia.

Although current findings suggest that the degree of T2DM, dependent on the presence and severity of hyperglycaemia and hyperlipidaemia, is of influence for the cardioprotective capacity of anaesthetics, there are no direct studies available that investigated cardioprotective strategies in animals with this diabetic entity.

\section{Experimental options to improve perioperative myocardial metabolism}

The reduced adaptability of the metabolic altered heart to ischaemic injury and cardioprotective interventions warrants further investigation of treatment strategies that optimise myocardial substrate metabolism before surgery. It is suggested that volatile anaesthesia induces a switch from myocardial fatty acid to glucose metabolism. In the metabolically altered heart, however, myocardial substrate metabolism is shifted to increased fatty acid and decreased glucose metabolism. Accordingly, the effect of volatile anaesthetics seems blunted in the metabolic altered heart. As a consequence, an improvement of the metabolic flexibility of the heart may be an important target. Figure 2 shows a hypothetical overview of the effects of different conditions on myocardial substrate metabolism.

\section{Pharmacological interventions}

Improvement of myocardial metabolic flexibility may be achieved by shifting myocardial substrate metabolism to glucose metabolism. This can be induced by 1) altering 


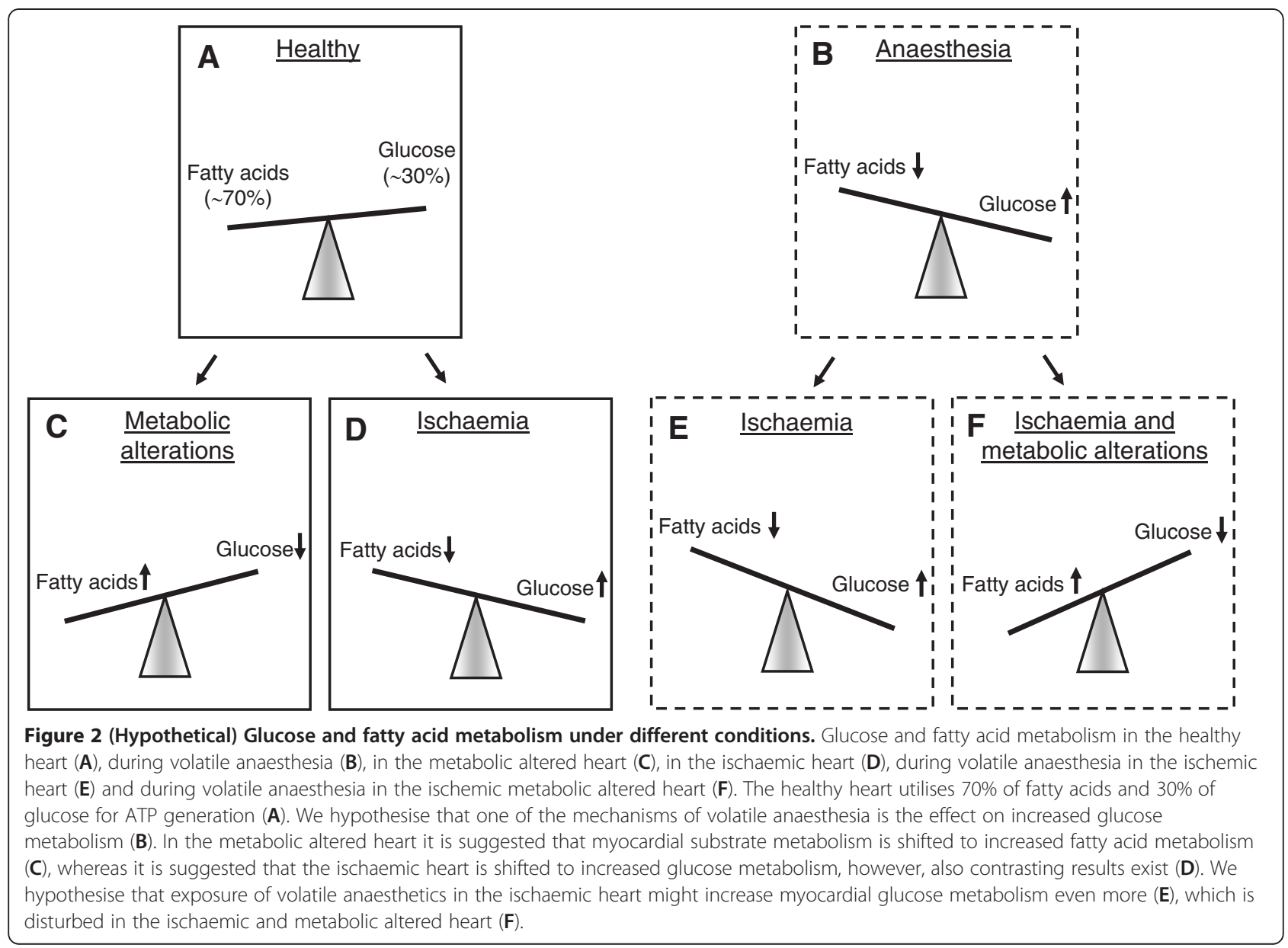

substrate supply, 2) inhibition of fatty acid oxidation and/or 3) improving insulin sensitivity. The next paragraphs provide an overview of pharmacological interventions in the experimental setting in the treatment of T2DM and/or myocardial ischaemic injury, which might reduce perioperative risk due to normalisation of metabolic derangements (Table 1).

\section{Inhibition of fatty acid metabolism}

Carnitine palmitoyl transferase 1 (CPT-1) is a rate-limiting step of fatty acid oxidation. Several inhibitors of CPT-1 have shown beneficial effects during ischaemia and reperfusion in rats, such as etomoxir [89-91], perhexiline [92] and oxfenicine [92,93]. However, not all of these variants of CPT-1 inhibitors are yet registered for clinical use. Other possibilities to reduce fatty acid oxidation are trimetazidine (3-ketoacyl CoA thiolase inhibitor) [94,95], ranolazine (partial fatty acid oxidation inhibitor) [96,97] and dichloroacetate (DCA; pyruvate dehydrogenase kinase inhibitor) [98], which have protective characteristics during myocardial ischaemia in rats. One of the suggested mechanisms underlying the beneficial effects of these substances is the stimulation of myocardial glucose oxidation $[96,98,99]$. However, as insulin resistance is a hallmark of the metabolic altered heart, stimulation of glucose metabolism via inhibition of fatty acid metabolism may be blunted during insulin resistance. Unfortunately, the effect of volatile anaesthesia in combination with inhibition of fatty acid metabolism on ischaemic injury in T2DM hearts has not been studied yet, however, based on the use of these fatty acid inhibitors in models of T2DM it may be deduced that insulin resistance might be improved, thereby improving the impact of anaesthesiainduced cardioprotection.

\section{Insulin}

Glucose-insulin-potassium (GIK) infusion has been shown to reduce mortality in non-diabetic $[100,101]$ and diabetic patients [102], and to reduce infarct size in rats [103]. However, also other results exist $[104,105]$. In the perioperative context, GIK infusion lowered glucose levels and other metabolic parameters [106] and improved perioperative outcomes, enhanced survival, decreased the incidence of ischaemic events [107] in T2DM patients during coronary artery bypass grafting (CABG). 
Table 1 Overview of pharmacological interventions in the experimental setting

\begin{tabular}{|c|c|c|c|}
\hline Drug & Applicability & Advantages & Side-effects \\
\hline \multicolumn{4}{|c|}{ Fatty acid metabolism inhibitors } \\
\hline Etomoxir & T2DM, infarction [89-91] & Stimulation glucose oxidation [99] & - \\
\hline Perhexiline & T2DM, infarction [92] & Stimulation glucose oxidation & - \\
\hline Oxfenicine & T2DM, infarction $[92,93]$ & Stimulation glucose oxidation & - \\
\hline Trimetazidine & T2DM, infarction $[94,95]$ & Stimulation glucose oxidation & - \\
\hline Ranolazine & T2DM, infarction $[96,97]$ & Stimulation glucose oxidation [96] & - \\
\hline Dichloroacetate & T2DM, infarction [98] & Stimulation glucose oxidation [98] & - \\
\hline \multicolumn{4}{|l|}{ Insulin } \\
\hline Glucose-insulin-potassium & Infarction [103] & Stimulation glucose oxidation & Hypoglycaemia \\
\hline \multirow[t]{2}{*}{ Insulin } & $\mathrm{T} 2 \mathrm{DM}$ & Reduction glucose levels & Hypoglycaemia \\
\hline & Infarction $[108,109]$ & Stimulation glucose oxidation & Hypoglycaemia \\
\hline \multicolumn{4}{|l|}{ PPAR agonists } \\
\hline \multirow[t]{2}{*}{ Fibrates (PPARa) } & T2DM [47] & Reduction lipids & Myopathy \\
\hline & Infarction [115-117] & Reduction lipids & Myopathy \\
\hline \multirow[t]{2}{*}{ Thiozolidinediones (PPARY) } & T2DM [121,122] & Insulin sensitizer & Increased risk heart attacks \\
\hline & Infarction $[44,48,115,119,120]$ & Insulin sensitizer & Increased risk heart attacks \\
\hline \multicolumn{4}{|l|}{ Biguanide } \\
\hline Metformin & T2DM, infarction [125-128] & Stimulation glucose oxidation & Lactic acidosis \\
\hline \multicolumn{4}{|l|}{ GLP1 } \\
\hline GLP1 & T2DM, infarction [130] & Reduction glucose & Short half-life \\
\hline Exendin-4 & T2DM, infarction [131] & Reduction glucose & Hypoglycaemia \\
\hline Exenatide & T2DM, infarction [132] & Reduction glucose & Hypoglycaemia \\
\hline Liraglutide & T2DM, infarction $[133,134]$ & Reduction glucose & Hypoglycaemia \\
\hline
\end{tabular}

T2DM, type 2 diabetes mellitus; PPAR, peroxisome proliferators-activated receptor; GLP-1, glucagon-like peptide 1.

The beneficial effects of GIK include increasing myocardial glucose uptake and glycogen content. It is suggested that insulin itself might be the major cardioprotective component. In isolated rat hearts, administration of insulin protected against ischaemia and reperfusion injury $[108,109]$. However, insulin treatment was not able to restore the lost cardioprotective capacity of sevoflurane in the type 1 diabetic heart [87].

Disadvantages of insulin infusion might be hypoglycaemia, which could be circumvented by additional glucose infusion (hyperinsulinaemic euglycaemic clamping). Insulin and dextrose infusion normalised postoperative whole body insulin sensitivity and substrate utilization in healthy patients during elective surgery [110]. During cardiac surgery, insulin and dextrose infusion maintained normoglycaemia in healthy [111] and T2DM [112] patients, however, hypolipidaemia was observed [113]. Further, it was shown in diabetic patients that isoflurane reduced postoperative markers of ischaemic injury after CABG, indicating a cardioprotective effect of isoflurane [114]. Preoperative treatment with glibenclamide prevented this protective effect, which was restored by changing glibenclamide preoperatively to insulin [114]. Taken together, these data suggest that perioperative glucose control by insulin may decrease the risk of postoperative mortality and morbidity.

\section{Peroxisome proliferator-activated receptor agonists}

Fibrates are selective peroxisome proliferator-activated receptor (PPAR) $\alpha$ agonists, which have lipid lowering effects, thereby improving insulin sensitivity. PPAR $\alpha$ activation has been shown to reduce myocardial ischaemia and reperfusion injury in rat hearts $[115,116]$. Activation of PPAR $\alpha$ in T2DM Goto-Kakizaki rat hearts reduced ischaemic injury [117], whereas in T2DM $d b / d b$ mice PPAR $\alpha$ activation did not affect the sensitivity to ischaemia and reperfusion even while myocardial glucose oxidation was increased and myocardial fatty acid oxidation reduced [47]. Moreover, sevoflurane reduced PPAR $\alpha$ in whole blood compared to baseline [118], whereas during CABG sevoflurane reduced PPAR $\alpha$ in right atrial tissue compared to propofol [11]. Based on these contrasting results, it might be interesting to study the effects of PPAR $\alpha$ agonists combined with volatile anaesthesia.

Insulin-sensitizing drugs, such as thiazolidinediones have beneficial effects by activation of PPAR $\gamma$. Rosiglitazone is 
the most selective PPARY agonist and is widely used in the treatment of T2DM. PPAR $\gamma$ agonists have been shown to reduce myocardial ischaemia and reperfusion injury in rats $[48,115,119,120]$. Rosiglitazone has been shown to increase myocardial GLUT4 translocation [121] and glucose metabolism [122] in healthy and T2DM rat hearts. During myocardial ischaemia and reperfusion, it was shown that rosiglitazone treatment normalised ischaemic injury by improvement of the reduced glucose uptake in obese Zucker rats [44], and reduced ischaemic injury by improved myocardial insulin sensitivity and glucose oxidation in T2DM Zucker diabetic fatty rats [48], suggesting a role for PPAR $\gamma$ to influence myocardial substrate metabolism to optimise metabolic flexibility during myocardial ischaemia and reperfusion. Accordingly, it was shown that desflurane-induced cardioprotection during ischaemia and reperfusion was abolished by PPAR $\gamma$ inhibition in rabbits [123], suggesting a role for PPAR $\gamma$ in improvement of metabolic flexibility.

\section{Metformin}

Metformin, a biguanide with antihyperglycaemic properties, has been widely used in the treatment of obesity and T2DM and exerts its actions by enhancing insulin sensitivity. It is suggested that the glucose-lowering effects of metformin are mediated through the activation of AMPK, which has also been indicated to play an important protective role in the ischaemic mouse heart [124,125]. In non-diabetic rat hearts, metformin protects against ischaemic injury [126,127]. Accordingly, metformin provides cardioprotection against ischaemic injury in T2DM hearts from animals in vivo [125], but not in vitro [128]. The effects of volatile anaesthesia and metformin in ischaemic and T2DM hearts has not been studied yet. However, it has been shown that AMPK is involved in anaesthetic cardioprotection [41,129].

\section{Glucagon-like peptide 1}

Glucagon-like peptide 1 (GLP1) is a gut incretin hormone that is released in response to nutrient intake, stimulates insulin secretion and exerts insulinotropic and insulinomimetic properties. GLP1 has been shown to be protective in ischaemic rat hearts [130].

GLP1 has a short half-life of several minutes, due to rapid breakdown by dipeptidyl peptidase IV (DPP4). Exendin-4 is a peptide derived from the saliva of the gila monster which mimics GLP1, but is resistant to degradation by DPP4. Exenatide and liraglutide are synthetic GLP1 analogues, which mimic human GLP1 and are currently used for blood glucose-lowering therapy in T2DM. Exendin-4 [131], exenatide [132] and liraglutide [133] have been shown to reduce infarct size in animals, but also a neutral effect of liraglutide on myocardial infarct size was found [134]. Another possibility to circumvent the rapid breakdown of GLP1 is the use of a DPP4 inhibitor. However, inhibition of DPP4 by valine pyrrolidide in rats [130] or in DPP4 knockout mice [135] was not protective during myocardial infarction. It is suggested that the cardioprotective effect is a consequence of insulin, however, GLP1 has cardioprotective effects both in vivo and in vitro, whereby the latter is in absence of circulating insulin levels [130], suggesting a role for GLP1 in cardioprotection.

The mechanism behind the cardioprotective properties of GLP1 may, amongst others [136], rely on improving myocardial glucose metabolism. GLP1 increased glucose uptake in isolated mouse [137] and isolated healthy [138], hypertensive [139] and ischaemic/reperfused [138] rat hearts. Moreover, exenatide increased myocardial glucose uptake in healthy [140] and insulin resistant dilated cardiomyopathy [141] mice, whereas it did not alter myocardial glucose uptake in type 2 diabetic patients [142].

Exposure of healthy rats to isoflurane anaesthesia decreased GLP1 levels, without affecting DPP4 activity, insulin and glucose levels [143], suggesting impaired GLP1 secretion during isoflurane anaesthesia. However, the effect of volatile anaesthetics on GLP1 is scarcely studied and therefore no conclusion van be drawn.

Taken together, the above-discussed pharmacological interventions suggest that improving insulin sensitivity, and thereby improving myocardial flexibility, may be the most beneficial option in metabolically altered hearts in order to restore cardioprotective mechanisms. However, according to current clinical practice, oral hypoglycaemic agents are usually withheld before surgery in order to avoid associated adverse effects, such as perioperative hypoglycaemia or lactic acidosis. Therefore the (clinical) feasibility and safety of the proposed interventions should be carefully studied and weighted against the potential risk of these adverse effects.

\section{Preoperative health risk improvement}

Based on 7 risk factors (physical inactivity, dietary pattern, obesity, smoking, high cholesterol, hypertension and elevated blood glucose levels), the 2020 impact goal of the American Heart Association is: "to improve the cardiovascular health by $20 \%$ while reducing deaths from cardiovascular diseases and stroke by 20\%" [144]. Another possibility besides pharmacological intervention is preoperative lifestyle intervention, such as changing the dietary intake and stimulation of physical activity thereby losing weight and improving insulin sensitivity.

It has been shown by reducing dietary fat in rodents that diet-induced obesity is reversible [145-147]. In contrast, diet-induced obesity was not reversed by withdrawal of an energy dense diet [148]. Reversibility of diet-induced obesity is independent of the duration of the obese state [146], whereas long-term diet feeding did not reversed 
obesity [145]. Overall, these data suggest that changing dietary intake may have beneficial effects on health. However, there is only limited literature available that describes the effects of changing dietary balance on the heart.

In western diet-fed rats, lowering caloric intake improved systolic and diastolic function and prevented sevoflurane-induced cardiodepression (van den Brom et al., unpublished observations). Accordingly, pacing-induced cardioprotection was lost by diet-induced hypercholesterolaemia, but restored after reversion to control diet [149], whereas caloric restriction by itself in healthy rats also has cardioprotective properties [150]. In conclusion, restriction of dietary fat seems an effective treatment to improve metabolic flexibility of the heart and thereby may be a possibility to reduce perioperative risk.

Obesity and T2DM are closely related to physical inactivity, and exercise could be a possible lifestyle intervention to reduce perioperative risk. The benefits of exercise with respect to obesity and T2DM are already recognized clinically [151]. However, the effects of exercise on myocardial infarction are contradictory. Exercise did not reduce myocardial ischaemic injury in rats [152], whereas others showed that exercise had protective effects in rat hearts [153-155]. The question remains if exercise has beneficial effects in obese and T2DM on myocardial function and ischaemia and reperfusion injury. Exercise was shown to reverse diet-induced obesity, insulin resistance and cardiomyocyte dysfunction [147], however, the effects of exercise on myocardial infarction in obese and T2DM with and without the effects of volatile anaesthesia is not known. Based on the above described results exercise might be a possible lifestyle intervention to reduce perioperative risk.

\section{Conclusions}

Over the years, several mechanisms that are involved in anaesthesia-induced cardioprotection have been evaluated in the experimental setting. The existing evidence suggests that the obese and/or T2DM heart is less adaptable to cardioprotective interventions and that anaesthesia-induced cardioprotection is just a "healthy heart phenomenon".

Differences between experimental models, the type of metabolic disease and the severity of myocardial substrate derangements challenge the identification of unifying mechanisms related to anaesthesia-induced cardioprotection in cases of obesity and T2DM. It might be deduced that interventional options should focus on recovery of the metabolic flexibility of the heart, especially by improving insulin sensitivity. Although changing lifestyle seems promising to reduce the susceptibility of the heart to intraoperative ischaemia and reperfusion injury, experimental data has not been translated into clinical data. Therefore more studies are required to elucidate whether these interventions have beneficial effects on perioperative outcome.

\section{Abbreviations}

AMPK AMP: Activated Protein Kinase; ATP: Adenosine Triphosphate; CABG: Coronary Artery Bypass Grafting; CPT: Carnitine Palmitoyl Transferase; DCA: Dichloroacetate; DPP: Dipeptidyl Peptidase; FABPpm: Plasma Membrane Fatty Acid Binding Protein; FAT/CD36: Fatty Acid Translocase CD36; FATP: Fatty Acid Transport Protein; GIK: Glucose-Insulin-Potassium; GLP: Glucagon-Like Peptide; GLUT: Glucose Transporter; PPAR: Peroxisome Proliferator-Activated Receptor; T2DM: Type 2 Diabetes Mellitus.

\section{Competing interests}

The authors declare that they have no competing interests.

\section{Authors' contributions}

CEvdB wrote the manuscript. CSEB, SAL and RAB reviewed the manuscript. $C B$ wrote, reviewed and edited the manuscript. All authors read and approved the final manuscript.

\section{Acknowledgements}

This work was supported by the Young Investigator Grant of the Dutch Society of Anesthesiologists [YIG 2010] and a Clinical Fellow Stipendium, ZonMw, the Netherlands Organization for Scientific Research [NWO, 4000703-97-305]

Received: 14 January 2013 Accepted: 21 February 2013

Published: 4 March 2013

\section{References}

1. Fleisher LA, Beckman JA, Brown KA, Calkins H, Chaikof E, Fleischmann KE, Freeman WK, Froehlich JB, Kasper EK, Kersten JR, Riegel B, Robb JF, Smith SC Jr, Jacobs AK, Adams CD, Anderson JL, Antman EM, Buller CE, Creager MA, Ettinger SM, Faxon DP, Fuster V, Halperin JL, Hiratzka LF, Hunt SA, et al: ACC/AHA 2007 guidelines on perioperative cardiovascular evaluation and care for noncardiac surgery: a report of the american college of cardiology/american heart association task force on practice guidelines (writing committee to revise the,guidelines on perioperative cardiovascular evaluation for noncardiac surgery): developed in collaboration with the american society of echocardiography, american society of nuclear cardiology, heart rhythm society, society of cardiovascular anesthesiologists, society for cardiovascular angiography and interventions, society for vascular medicine and biology, and society for vascular surgery. Circulation 2002, 2007(116):e418-e499.

2. Gupta PK, Gupta H, Sundaram A, Kaushik M, Fang X, Miller WJ, Esterbrooks DJ, Hunter CB, Pipinos II, Johanning JM, Lynch TG, Forse RA, Mohiuddin SM, Mooss AN: Development and validation of a risk calculator for prediction of cardiac risk after surgery. Circulation 2011, 124:381-387.

3. Unwin N, Whiting D, Guariguata L, Hennis A, Husseini A, Ji L, KissimovaSkarbek K, Libman I, Mayer-Davis E, Motala A, Narayan V, Ramachandran A, Roglic G, Sham J, Wareham N, Zhang P: IDF diabetes atlas 2011. 5th edition. Brussels: International Diabetes Federation; 2011.

4. Preis SR, Pencina MJ, Hwang SJ, D'Agostino RB Sr, Savage PJ, Levy D, Fox CS: Trends in cardiovascular disease risk factors in individuals with and without diabetes mellitus in the Framingham heart study. Circulation 2009, 120:212-220

5. Lee TH, Marcantonio ER, Mangione CM, Thomas EJ, Polanczyk CA, Cook EF Sugarbaker DJ, Donaldson MC, Poss R, Ho KK, Ludwig LE, Pedan A, Goldman L: Derivation and prospective validation of a simple index for prediction of cardiac risk of major noncardiac surgery. Circulation 1999, 100:1043-1049.

6. Frassdorf J, De Hert S, Schlack W: Anaesthesia and myocardial ischaemia/ reperfusion injury. Br J Anaesth 2009, 103:89-98.

7. De Hert SG, Preckel B, Hollmann MW, Schlack WS: Drugs mediating myocardial protection. Eur J Anaesthesiol 2009, 26:985-995.

8. Huhn $\mathrm{R}$, Heinen A, Hollmann MW, Schlack W, Preckel B, Weber NC: Cyclosporine $A$ administered during reperfusion fails to restore cardioprotection in prediabetic Zucker obese rats in vivo. Nutr Metab Cardiovasc Dis 2010, 20:706-712. 
9. Kehl F, Krolikowski JG, Mraovic B, Pagel PS, Warltier DC, Kersten JR: Hyperglycemia prevents isoflurane-induced preconditioning against myocardial infarction. Anesthesiology 2002, 96:183-188.

10. Lucchinetti E, Wang L, Ko KW, Troxler H, Hersberger M, Zhang L, Omar MA, Lopaschuk GD, Clanachan AS, Zaugg M: Enhanced glucose uptake via GLUT4 fuels recovery from calcium overload after ischaemia-reperfusion injury in sevoflurane- but not propofol-treated hearts. Br J Anaesth 2011, 106:792-800.

11. Lucchinetti E, Hofer C, Bestmann L, Hersberger M, Feng J, Zhu M, Furrer L, Schaub MC, Tavakoli R, Genoni M, Zollinger A, Zaugg M: Gene regulatory control of myocardial energy metabolism predicts postoperative cardiac function in patients undergoing off-pump coronary artery bypass graft surgery: inhalational versus intravenous anesthetics. Anesthesiology 2007 106:444-457.

12. Wang $\mathrm{L}$, Ko KW, Lucchinetti $\mathrm{E}$, Zhang L, Troxler $\mathrm{H}$, Hersberger M, Omar MA Posse de Chaves El, Lopaschuk GD, Clanachan AS, Zaugg M: Metabolic profiling of hearts exposed to sevoflurane and propofol reveals distinct regulation of fatty acid and glucose oxidation: CD36 and pyruvate dehydrogenase as key regulators in anesthetic-induced fuel shift. Anesthesiology 2010, 113:541-551.

13. Winterstein H: Ueber die Sauerstoffatmung des isolierten Saeugetierherzens. Z Allg Physiol 1904, 4:339-359.

14. Stanley WC, Lopaschuk GD, McCormack JG: Regulation of energy substrate metabolism in the diabetic heart. Cardiovasc Res 1997, 34:25-33.

15. Carley AN, Severson DL: Fatty acid metabolism is enhanced in type 2 diabetic hearts. Biochim Biophys Acta 2005, 1734:112-126.

16. Neely JR, Rovetto MJ, Oram JF: Myocardial utilization of carbohydrate and lipids. Prog Cardiovasc Dis 1972, 15:289-329.

17. Taegtmeyer H: Glycogen in the heart-an expanded view. J Mol Cell Cardiol 2004, 37:7-10.

18. Shepherd PR, Kahn BB: Glucose transporters and insulin action-implications for insulin resistance and diabetes mellitus. N Engl J Med 1999, 341:248-257.

19. Coort SL, Bonen A, van der Vusse GJ, Glatz JF, Luiken JJ: Cardiac substrate uptake and metabolism in obesity and type-2 diabetes: role of sarcolemmal substrate transporters. Mol Cell Biochem 2007, 299:5-18.

20. Lewin TM, Coleman RA: Regulation of myocardial triacylglycerol synthesis and metabolism. Biochim Biophys Acta 2003, 1634:63-75.

21. Kerner J, Hoppel C: Fatty acid import into mitochondria. Biochim Biophys Acta 2000, 1486:1-17.

22. Stanley WC, Recchia FA, Lopaschuk GD: Myocardial substrate metabolism in the normal and failing heart. Physiol Rev 2005, 85:1093-1129.

23. Saddik M, Lopaschuk GD: Myocardial triglyceride turnover and contribution to energy substrate utilization in isolated working rat hearts. J Biol Chem 1991, 266:8162-8170.

24. Lopaschuk GD, Ussher JR, Folmes CD, Jaswal JS, Stanley WC: Myocardial fatty acid metabolism in health and disease. Physiol Rev 2010, 90:207-258.

25. van den Brom CE, Bosmans JW, Vlasblom R, Handoko ML, Huisman MC Lubberink M, Molthoff CF, Lammertsma AA, Ouwens DM, Diamant M, Boer C: Diabetic cardiomyopathy in Zucker diabetic fatty rats: the forgotten right ventricle. Cardiovasc Diabetol 2010, 9:25.

26. van den Brom CE, Huisman MC, Vlasblom R, Boontje NM, Duijst S, Lubberink M, Molthoff CF, Lammertsma AA, Van der Velden J, Boer C, Ouwens DM, Diamant M: Altered myocardial substrate metabolism is associated with myocardial dysfunction in early diabetic cardiomyopathy in rats: studies using positron emission tomography. Cardiovasc Diabetol 2009, 8:39.

27. Jaswal JS, Keung W, Wang W, Ussher JR, Lopaschuk GD: Targeting fatty acid and carbohydrate oxidation-a novel therapeutic intervention in the ischemic and failing heart. Biochim Biophys Acta 1813, 2011:1333-1350.

28. Opie LH: The heart; Physiology and Metabolism. New York: Raven Press; 1991.

29. Kannel WB, Hjortland M, Castelli WP: Role of diabetes in congestive heart failure: the Framingham study. Am J Cardiol 1974, 34:29-34

30. Rennert G, Saltz-Rennert H, Wanderman K, Weitzman S: Size of acute myocardial infarcts in patients with diabetes mellitus. Am J Cardiol 1985, 55:1629-1630.

31. How OJ, Aasum E, Severson DL, Chan WY, Essop MF, Larsen TS: Increased myocardial oxygen consumption reduces cardiac efficiency in diabetic mice. Diabetes 2006, 55:466-473.

32. Paulson DJ: The diabetic heart is more sensitive to ischemic injury. Cardiovasc Res 1997, 34:104-112.

33. van den Brom CE, Bulte CS, Kloeze BM, Loer SA, Boer C, Bouwman RA: High fat diet-induced glucose intolerance impairs myocardial function, but not myocardial perfusion during hyperaemia: a pilot study. Cardiovasc Diabetol 2012, 11:74

34. Ivanova M, Janega P, Matejikova J, Simoncikova P, Pancza D, Ravingerova T, Barancik M: Activation of Akt kinase accompanies increased cardiac resistance to ischemia/reperfusion in rats after short-term feeding with lard-based highfat diet and increased sucrose intake. Nutr Res 2011, 31:631-643.

35. Rennison JH, McElfresh TA, Chen X, Anand VR, Hoit BD, Hoppel CL, Chandler MP: Prolonged exposure to high dietary lipids is not associated with lipotoxicity in heart failure. J Mol Cell Cardiol 2009, 46:883-890.

36. Jordan JE, Simandle SA, Tulbert CD, Busija DW, Miller AW: Fructose-fed rats are protected against ischemia/reperfusion injury. J Pharmacol Exp Ther 2003, 307:1007-1011.

37. Morgan EE, Rennison JH, Young ME, McElfresh TA, Kung TA, Tserng KY, Hoit BD, Stanley WC, Chandler MP: Effects of chronic activation of peroxisome proliferator-activated receptor-alpha or high-fat feeding in a rat infarct model of heart failure. Am J Physiol Heart Circ Physiol 2006, 290:H1899-H1904.

38. Rennison JH, McElfresh TA, Okere IC, Vazquez EJ, Patel HV, Foster AB, Patel KK, Chen Q, Hoit BD, Tserng KY, Hassan MO, Hoppel CL, Chandler MP: Highfat diet postinfarction enhances mitochondrial function and does not exacerbate left ventricular dysfunction. Am J Physiol Heart Circ Physiol 2007, 292:H1498-H1506.

39. Mozaffari MS, Patel C, Ballas C, Schaffer SW: Effects of excess salt and fat intake on myocardial function and infarct size in rat. Life Sci 2006, 78:1808-1813

40. Berthiaume JM, Young ME, Chen X, McElfresh TA, Yu X, Chandler MP Normalizing the metabolic phenotype after myocardial infarction: impact of subchronic high fat feeding. J Mol Cell Cardiol 2012, 53:125-133.

41. Song T, LV LY, Xu J, Tian ZY, Cui WY, Wang QS, Qu G, Shi XM: Diet-induced obesity suppresses sevoflurane preconditioning against myocardial ischemia-reperfusion injury: role of AMP-activated protein kinase pathway. Exp Biol Med (Maywood) 2011, 236:1427-1436.

42. Morel S, Berthonneche C, Tanguy S, Toufektsian MC, Perret P, Ghezzi C, de Leiris J, Boucher F: Early pre-diabetic state alters adaptation of myocardial glucose metabolism during ischemia in rats. Mol Cell Biochem 2005, 272:9-17.

43. Maddaford TG, Russell JC, Pierce GN: Postischemic cardiac performance in the insulin-resistant JCR:LA-cp rat. Am J Physio/ 1997, 273:H1187-H1192.

44. Sidell RJ, Cole MA, Draper NJ, Desrois M, Buckingham RE, Clarke K. Thiazolidinedione treatment normalizes insulin resistance and ischemic injury in the zucker Fatty rat heart. Diabetes 2002, 51:1110-1117.

45. Mozaffari MS, Schaffer SW: Myocardial ischemic-reperfusion injury in a rat model of metabolic syndrome. Obesity (Silver Spring) 2008, 16:2253-2258.

46. Thakker GD, Frangogiannis NG, Zymek PT, Sharma S, Raya JL, Barger PM, Taegtmeyer H, Entman ML, Ballantyne CM: Increased myocardial susceptibility to repetitive ischemia with high-fat diet-induced obesity. Obesity (Silver Spring) 2008, 16:2593-2600.

47. Aasum E, Hafstad AD, Severson DL, Larsen TS: Age-dependent changes in metabolism, contractile function, and ischemic sensitivity in hearts from $\mathrm{db} / \mathrm{db}$ mice. Diabetes 2003, 52:434-441.

48. Yue TL, Bao W, Gu JL, Cui J, Tao L, Ma XL, Ohlstein EH, Jucker BM: Rosiglitazone treatment in Zucker diabetic Fatty rats is associated with ameliorated cardiac insulin resistance and protection from ischemia/ reperfusion-induced myocardial injury. Diabetes 2005, 54:554-562.

49. Wang P, Chatham JC: Onset of diabetes in Zucker diabetic fatty (ZDF) rats leads to improved recovery of function after ischemia in the isolated perfused heart. Am J Physiol Endocrinol Metab 2004, 286:E725-E736.

50. Hoshida S, Yamashita N, Otsu K, Kuzuya T, Hori M: Cholesterol feeding exacerbates myocardial injury in Zucker diabetic fatty rats. Am J Physiol Heart Circ Physiol 2000, 278:H256-H262.

51. Higuchi M, Miyagi K, Nakasone J, Sakanashi M: Role of high glycogen in underperfused diabetic rat hearts with added norepinephrine. J Cardiovasc Pharmacol 1995, 26:899-907.

52. Cross HR, Opie LH, Radda GK, Clarke K: Is a high glycogen content beneficial or detrimental to the ischemic rat heart? A controversy resolved. Circ Res 1996, 78:482-491.

53. Feuvray D, Lopaschuk GD: Controversies on the sensitivity of the diabetic heart to ischemic injury: the sensitivity of the diabetic heart to ischemic injury is decreased. Cardiovasc Res 1997, 34:113-120.

54. Yao YT, Fang NX, Shi CX, Li LH: Sevoflurane postconditioning protects isolated rat hearts against ischemia-reperfusion injury. Chin Med J (Engl) 2010, 123:1320-1328. 
55. Bouwman RA, Vreden MJ, Hamdani N, Wassenaar LE, Smeding L, Loer SA, Stienen GJ, Lamberts RR: Effect of bupivacaine on sevoflurane-induced preconditioning in isolated rat hearts. Eur J Pharmacol 2010, 647:132-138.

56. Tosaka S, Tosaka R, Matsumoto S, Maekawa T, Cho S, Sumikawa K: Roles of cyclooxygenase 2 in sevoflurane- and olprinone-induced early phase of preconditioning and postconditioning against myocardial infarction in rat hearts. J Cardiovasc Pharmacol Ther 2011, 16:72-78.

57. Obal D, Dettwiler S, Favoccia C, Scharbatke H, Preckel B, Schlack W: The influence of mitochondrial KATP-channels in the cardioprotection of preconditioning and postconditioning by sevoflurane in the rat in vivo. Anesth Analg 2005, 101:1252-1260.

58. Lang $X E$, Wang $X$, Jin JH: Mechanisms of cardioprotection by isoflurane against I/R injury. Front Biosci 2013, 18:387-393.

59. Yao Y, Li L, Li L, Gao C, Shi C: Sevoflurane postconditioning protects chronically-infarcted rat hearts against ischemia-reperfusion injury by activation of pro-survival kinases and inhibition of mitochondrial permeability transition pore opening upon reperfusion. Biol Pharm Bull 2009, 32:1854-1861

60. Stadnicka A, Marinovic J, Ljubkovic M, Bienengraeber MW, Bosnjak ZJ: Volatile anesthetic-induced cardiac preconditioning. J Anesth 2007, 21:212-219.

61. Lattermann R, Schricker T, Wachter U, Georgieff M, Goertz A Understanding the mechanisms by which isoflurane modifies the hyperglycemic response to surgery. Anesth Analg 2001, 93:121-127.

62. Bouwman RA, Musters RJ, van Beek-Harmsen BJ, de Lange JJ, Boer C: Reactive oxygen species precede protein kinase C-delta activation independent of adenosine triphosphate-sensitive mitochondrial channel opening in sevoflurane-induced cardioprotection. Anesthesiology 2004 100:506-514.

63. Costa AD, Quinlan CL, Andrukhiv A, West IC, Jaburek M, Garlid KD: The direct physiological effects of mitoK(ATP) opening on heart mitochondria. Am J Physiol Heart Circ Physiol 2006, 290:H406-H415.

64. Flores JE, McFarland LM, Vanderbilt A, Ogasawara AK, Williams SP: The effects of anesthetic agent and carrier gas on blood glucose and tissue uptake in mice undergoing dynamic FDG-PET imaging: sevoflurane and isoflurane compared in air and in oxygen. Mol Imaging Biol 2008, 10:192-200.

65. Toyama H, Ichise M, Liow JS, Vines DC, Seneca NM, Modell KJ, Seidel J, Green MV, Innis RB: Evaluation of anesthesia effects on [18 F]FDG uptake in mouse brain and heart using small animal PET. NuCl Med Biol 2004, 31:251-256.

66. Kudoh A, Katagai H, Takazawa T: Sevoflurane increases glucose transport in skeletal muscle cells. Anesth Analg 2002, 95:123-128. table.

67. Ewart RB, Rusy BF, Bradford MW: Effects of enflurane on release of insulin by pancreatic islets in vitro. Anesth Analg 1981, 60:878-884

68. Tanaka K, Kawano T, Tsutsumi YM, Kinoshita M, Kakuta N, Hirose K, Kimura $M$, Oshita S: Differential effects of propofol and isoflurane on glucose utilization and insulin secretion. Life Sci 2011, 88:96-103.

69. Zuurbier CJ, Keijzers PJ, Koeman A, Van Wezel HB, Hollmann MW: Anesthesia's effects on plasma glucose and insulin and cardiac hexokinase at similar hemodynamics and without major surgical stress in fed rats. Anesth Analg 2008, 106:135-142

70. Kitamura T, Ogawa M, Kawamura G, Sato K, Yamada Y: The effects of sevoflurane and propofol on glucose metabolism under aerobic conditions in fed rats. Anesth Analg 2009, 109:1479-1485.

71. Kosiborod M, Rathore SS, Inzucchi SE, Masoudi FA, Wang Y, Havranek EP, Krumholz HM: Admission glucose and mortality in elderly patients hospitalized with acute myocardial infarction: implications for patients with and without recognized diabetes. Circulation 2005, 111:3078-3086.

72. Katakam PV, Jordan JE, Snipes JA, Tulbert CD, Miller AW, Busija DW: Myocardial preconditioning against ischemia-reperfusion injury is abolished in Zucker obese rats with insulin resistance. Am J Physiol Regul Integr Comp Physiol 2007, 292:R920-R926.

73. Wagner C, Kloeting I, Strasser RH, Weinbrenner C: Cardioprotection by postconditioning is lost in WOKW rats with metabolic syndrome: role of glycogen synthase kinase 3beta. J Cardiovasc Pharmacol 2008, 52:430-437.

74. Ferdinandy P, Szilvassy Z, Horvath LI, Csont T, Csonka C, Nagy E, Szentgyorgyi R, Nagy I, Koltai M, Dux L: Loss of pacing-induced preconditioning in rat hearts: role of nitric oxide and cholesterolenriched diet. J Mol Cell Cardiol 1997, 29:3321-3333.

75. Kocic I, Konstanski Z, Kaminski M, Dworakowska D, Dworakowski R: Experimental hyperlipidemia prevents the protective effect of ischemic preconditioning on the contractility and responsiveness to phenylephrine of rat-isolated stunned papillary muscle. Gen Pharmacol 1999, 33:213-219.

76. Zhang FJ, Ma LL, Wang WN, Oian LB, Yang MJ, Yu J, Chen G, Yu LN, Yan M: Hypercholesterolemia abrogates sevoflurane-induced delayed preconditioning against myocardial infarct in rats by alteration of nitric oxide synthase signaling. Shock 2012, 37:485-491.

77. Malmberg K, Norhammar A, Wedel H, Ryden L: Glycometabolic state at admission: important risk marker of mortality in conventionally treated patients with diabetes mellitus and acute myocardial infarction: longterm results from the diabetes and insulin-glucose infusion in acute myocardial infarction (DIGAMI) study. Circulation 1999, 99:2626-2632.

78. Weber NC, Goletz C, Huhn R, Grueber Y, Preckel B, Schlack W, Ebel D: Blockade of anaesthetic-induced preconditioning in the hyperglycaemic myocardium: the regulation of different mitogen-activated protein kinases. Eur J Pharmacol 2008, 592:48-54.

79. Kehl F, Krolikowski JG, Weihrauch D, Pagel PS, Warltier DC, Kersten JR $\mathrm{N}$-acetylcysteine restores isoflurane-induced preconditioning against myocardial infarction during hyperglycemia. Anesthesiology 2003, 98:1384-1390.

80. Huhn R, Heinen A, Weber NC, Hollmann MW, Schlack W, Preckel B: Hyperglycaemia blocks sevoflurane-induced postconditioning in the rat heart in vivo: cardioprotection can be restored by blocking the mitochondrial permeability transition pore. Br J Anaesth 2008, 100:465-471.

81. Kersten JR, Toller WG, Gross ER, Pagel PS, Warltier DC: Diabetes abolishes ischemic preconditioning: role of glucose, insulin, and osmolality. Am J Physiol Heart Circ Physiol 2000, 278:H1218-H1224.

82. Tanaka K, Kehl F, Gu W, Krolikowski JG, Pagel PS, Warltier DC, Kersten JR: Isoflurane-induced preconditioning is attenuated by diabetes. Am J Physiol Heart Circ Physiol 2002, 282:H2018-H2023.

83. Raphael J, Gozal Y, Navot N, Zuo Z: Hyperglycemia inhibits anestheticinduced postconditioning in the rabbit heart via modulation of phosphatidylinositol-3-kinase/Akt and endothelial nitric oxide synthase signaling. J Cardiovasc Pharmacol 2010, 55:348-357.

84. Kristiansen SB, Lofgren B, Stottrup NB, Khatir D, Nielsen-Kudsk JE, Nielsen TT, Botker HE, Flyvbjerg A: Ischaemic preconditioning does not protect the heart in obese and lean animal models of type 2 diabetes. Diabetologia 2004, 47:1716-1721.

85. Miki T, Itoh T, Sunaga D, Miura T: Effects of diabetes on myocardial infarct size and cardioprotection by preconditioning and postconditioning Cardiovasc Diabetol 2012, 11:67.

86. Tsang A, Hausenloy DJ, Mocanu MM, Carr RD, Yellon DM: Preconditioning the diabetic heart: the importance of Akt phosphorylation. Diabetes 2005, 54:2360-2364

87. Drenger B, Ostrovsky IA, Barak M, Nechemia-Arbely Y, Ziv E, Axelrod JH: Diabetes blockade of sevoflurane postconditioning is Not restored by insulin in the Rat heart: phosphorylated signal transducer and activator of transcription 3- and phosphatidylinositol 3-kinase-mediated inhibition. Anesthesiology 2011, 114:1364-1372.

88. Paiva MA, Rutter-Locher Z, Goncalves LM, Providencia LA, Davidson SM, Yellon DM, Mocanu MM: Enhancing AMPK activation during ischemia protects the diabetic heart against reperfusion injury. Am J Physiol Heart Circ Physiol 2011, 300:H2123-H2134.

89. Penna C, Mancardi D, Gattullo D, Pagliaro P: Myocardial protection from ischemic preconditioning is not blocked by sub-chronic inhibition of carnitine palmitoyltransferase I. Life Sci 2005, 77:2004-2017.

90. Lopaschuk GD, Spafford MA, Davies NJ, Wall SR: Glucose and palmitate oxidation in isolated working rat hearts reperfused after a period of transient global ischemia. Circ Res 1990, 66:546-553.

91. Lopaschuk GD, Saddik M: The relative contribution of glucose and fatty acids to ATP production in hearts reperfused following ischemia. $\mathrm{Mol} \mathrm{Cell}$ Biochem 1992, 116:111-116.

92. Kennedy JA, Kiosoglous AJ, Murphy GA, Pelle MA, Horowitz JD: Effect of perhexiline and oxfenicine on myocardial function and metabolism during low-flow ischemia/reperfusion in the isolated rat heart. J Cardiovasc Pharmacol 2000, 36:794-801.

93. Molaparast-Saless F, Liedtke AJ, Nellis SH: Effects of the fatty acid blocking agents, oxfenicine and 4-bromocrotonic acid, on performance in aerobic and ischemic myocardium. J Mol Cell Cardiol 1987, 19:509-520.

94. Kara AF, Demiryurek S, Celik A, Tarakcioglu M, Demiryurek AT: Effects of trimetazidine on myocardial preconditioning in anesthetized rats. Eur J Pharmacol 2004, 503:135-145. 
95. Mouquet F, Rousseau D, Domergue-Dupont V, Grynberg A, Liao R: Effects of trimetazidine, a partial inhibitor of fatty acid oxidation, on ventricular function and survival after myocardial infarction and reperfusion in the rat. Fundam Clin Pharmacol 2010, 24:469-476.

96. McCormack JG, Barr RL, Wolff AA, Lopaschuk GD: Ranolazine stimulates glucose oxidation in normoxic, ischemic, and reperfused ischemic rat hearts. Circulation 1996, 93:135-142.

97. Wang P, Fraser H, Lloyd SG, McVeigh JJ, Belardinelli L, Chatham JC: A comparison between ranolazine and CVT-4325, a novel inhibitor of fatty acid oxidation, on cardiac metabolism and left ventricular function in rat isolated perfused heart during ischemia and reperfusion. J Pharmacol Exp Ther 2007, 321:213-220.

98. McVeigh JJ, Lopaschuk GD: Dichloroacetate stimulation of glucose oxidation improves recovery of ischemic rat hearts. Am J Physiol 1990 259:H1079-H1085.

99. Lopaschuk GD, McNeil GF, McVeigh JJ: Glucose oxidation is stimulated in reperfused ischemic hearts with the carnitine palmitoyltransferase 1 inhibitor, Etomoxir. Mol Cell Biochem 1989, 88:175-179.

100. Diaz R, Paolasso EA, Piegas LS, Tajer CD, Moreno MG, Corvalan R, Isea JE, Romero G: Metabolic modulation of acute myocardial infarction. The ECLA (estudios cardiologicos latinoamerica) collaborative group. Circulation 1998, 98:2227-2234.

101. Di MS, Boldrini B, Conti U, Marcucci G, Morgantini E, Ferrannini C, Natali A: Effects of GIK (glucose-insulin-potassium) on stress-induced myocardial ischaemia. Clin Sci (Lond) 2010, 119:37-44.

102. Malmberg K, Ryden L, Hamsten A, Herlitz J, Waldenstrom A, Wedel H: Effects of insulin treatment on cause-specific one-year mortality and morbidity in diabetic patients with acute myocardial infarction. DIGAMI study group. Diabetes insulin-glucose in acute myocardial infarction. Eur Heart J 1996, 17:1337-1344

103. Jonassen AK, Aasum E, Riemersma RA, Mjos OD, Larsen TS: Glucose-insulinpotassium reduces infarct size when administered during reperfusion Cardiovasc Drugs Ther 2000, 14:615-623.

104. Ceremuzynski L, Budaj A, Czepiel A, Burzykowski T, Achremczyk P, SmielakKorombel W, Maciejewicz J, Dziubinska J, Nartowicz E, Kawka-Urbanek T, Piotrowski W, Hanzlik J, Cieslinski A, Kawecka-Jaszcz K, Gessek J, Wrabec K: Low-dose glucose-insulin-potassium is ineffective in acute myocardial infarction: results of a randomized multicenter Pol-GIK trial. CardiovasC Drugs Ther 1999, 13:191-200.

105. van der Horst IC, Zijlstra F, van 't Hof CJ, Doggen AW, de Boer MJ, Suryapranata H, Hoorntje JC, Dambrink JH, Gans RO, Bilo HJ: Glucoseinsulin-potassium infusion inpatients treated with primary angioplasty for acute myocardial infarction: the glucose-insulin-potassium study: a randomized trial. J Am Coll Cardiol 2003, 42:784-791.

106. Thomas DJ, Platt HS, Alberti KG: Insulin infusion (GIK) in the treatment of type 2 (non-insulin dependent) diabetes during the perioperative period. Br J Surg 1986, 73:898-901.

107. Lazar HL, Chipkin SR, Fitzgerald CA, Bao Y, Cabral H, Apstein CS: Tight glycemic control in diabetic coronary artery bypass graft patients improves perioperative outcomes and decreases recurrent ischemic events. Circulation 2004, 109:1497-1502

108. Doenst T, Richwine RT, Bray MS, Goodwin GW, Frazier OH, Taegtmeyer H: Insulin improves functional and metabolic recovery of reperfused working rat heart. Ann Thorac Surg 1999, 67:1682-1688.

109. Jonassen AK, Sack MN, Mjos OD, Yellon DM: Myocardial protection by insulin at reperfusion requires early administration and is mediated via Akt and p70s6 kinase cell-survival signaling. Circ Res 2001, 89:1191-1198.

110. Nygren JO, Thorell A, Soop M, Efendic S, Brismar K, Karpe F, Nair KS, Ljungqvist $\mathrm{O}$ : Perioperative insulin and glucose infusion maintains normal insulin sensitivity after surgery. Am J Physiol 1998, 275:E140-E148.

111. Sato H, Carvalho G, Sato T, Bracco D, Codere-Maruyama T, Lattermann R, Hatzakorzian R, Matsukawa T, Schricker T: Perioperative tight glucose control with hyperinsulinemic-normoglycemic clamp technique in cardiac surgery. Nutrition 2010, 26:1122-1129.

112. Carvalho G, Moore A, Qizilbash B, Lachapelle K, Schricker T: Maintenance of normoglycemia during cardiac surgery. Anesth Analg 2004, 99:319-324. table.

113. Zuurbier CJ, Hoek FJ, Van Dijk J, Abeling NG, Meijers JC, Levels JH, De Jonge E, de Mol BA, Van Wezel HB: Perioperative hyperinsulinaemic normoglycaemic clamp causes hypolipidaemia after coronary artery surgery. Br J Anaesth 2008, 100:442-450.
114. Forlani S, Tomai F, De Paulis R, Turani F, Colella DF, Nardi P, De Notaris S, Moscarelli M, Magliano G, Crea F, Chiariello L: Preoperative shift from glibenclamide to insulin is cardioprotective in diabetic patients undergoing coronary artery bypass surgery. J Cardiovasc Surg (Torino) 2004, 45:117-122.

115. Wayman NS, Hattori Y, McDonald MC, Mota-Filipe H, Cuzzocrea S, Pisano B, Chatterjee PK, Thiemermann C: Ligands of the peroxisome proliferatoractivated receptors (PPAR-gamma and PPAR-alpha) reduce myocardial infarct size. FASEB J 2002, 16:1027-1040.

116. Yue TL, Bao W, Jucker BM, Gu JL, Romanic AM, Brown PJ, Cui J, Thudium DT, Boyce R, Burns-Kurtis CL, Mirabile RC, Aravindhan K, Ohlstein EH: Activation of peroxisome proliferator-activated receptor-alpha protects the heart from ischemia/reperfusion injury. Circulation 2003, 108:2393-2399.

117. Bulhak AA, Jung C, Ostenson CG, Lundberg JO, Sjoquist PO, Pernow J: PPAR-alpha activation protects the type 2 diabetic myocardium against ischemia-reperfusion injury: involvement of the PI3-Kinase/Akt and NO pathway. Am J Physiol Heart Circ Physiol 2009, 296:H719-H727.

118. Lucchinetti E, Aguirre J, Feng J, Zhu M, Suter M, Spahn DR, Harter L, Zaugg M: Molecular evidence of late preconditioning after sevoflurane inhalation in healthy volunteers. Anesth Analg 2007, 105:629-640.

119. Yue TL, Chen J, Bao W, Narayanan PK, Bril A, Jiang W, Lysko PG, Gu JL, Boyce R, Zimmerman DM, Hart TK, Buckingham RE, Ohlstein EH: In vivo myocardial protection from ischemia/reperfusion injury by the peroxisome proliferator-activated receptor-gamma agonist rosiglitazone. Circulation 2001, 104:2588-2594.

120. Ito H, Nakano A, Kinoshita M, Matsumori A: Pioglitazone, a peroxisome proliferator-activated receptor-gamma agonist, attenuates myocardia ischemia/reperfusion injury in a rat model. Lab Invest 2003, 83:1715-1721.

121. Khandoudi N, Delerive P, Berrebi-Bertrand I, Buckingham RE, Staels B, Bril A: Rosiglitazone, a peroxisome proliferator-activated receptor-gamma, inhibits the Jun $\mathrm{NH}(2)$-terminal kinase/activating protein 1 pathway and protects the heart from ischemia/reperfusion injury. Diabetes 2002, 51:1507-1514

122. Shoghi Kl, Finck BN, Schechtman KB, Sharp T, Herrero P, Gropler RJ, Welch $\mathrm{MJ}$ : In vivo metabolic phenotyping of myocardial substrate metabolism in rodents: differential efficacy of metformin and rosiglitazone monotherapy. Circ Cardiovasc Imaging 2009, 2:373-381.

123. Lotz C, Lange M, Redel A, Stumpner J, Schmidt J, Tischer-Zeitz T, Roewer N, Kehl F: Peroxisome-proliferator-activated receptor gamma mediates the second window of anaesthetic-induced preconditioning. Exp Physiol 2011 96:317-324

124. Russell RR III, Li J, Coven DL, Pypaert M, Zechner C, Palmeri M, Giordano FJ, Mu J, Birnbaum MJ, Young LH: AMP-activated protein kinase mediates ischemic glucose uptake and prevents postischemic cardiac dysfunction, apoptosis, and injury. J Clin Invest 2004, 114:495-503.

125. Calvert JW, Gundewar S, Jha S, Greer JJ, Bestermann WH, Tian R, Lefer DJ: Acute metformin therapy confers cardioprotection against myocardial infarction via AMPK-eNOS-mediated signaling. Diabetes 2008, 57:696-705.

126. Yin M, van der Horst IC, van Melle JP, Qian C, van Gilst WH, Sillje HH, de Boer RA: Metformin improves cardiac function in a non-diabetic rat model of post-Ml heart failure. Am J Physiol Heart Circ Physiol 2011.

127. Paiva MA, Goncalves LM, Providencia LA, Davidson SM, Yellon DM, Mocanu MM: Transitory activation of AMPK at reperfusion protects the ischaemicreperfused rat myocardium against infarction. Cardiovasc Drugs Ther 2010, 24:25-32.

128. Lavanchy N, Christe G, Cand F, Wiernsperger N, Verdetti J: Effects of chronic treatment with glibenclamide and/or metformin on the resistance to ischaemia of isolated hearts from Zucker diabetic fatty rats (ZDF/GMI-fa/fa). Br J Diabetes Vasc Dis 2003, 3:375-380.

129. Lamberts RR, Onderwater G, Hamdani N, Vreden MJ, Steenhuisen J, Eringa EC, Loer SA, Stienen GJ, Bouwman RA: Reactive oxygen species-induced stimulation of 5/AMP-activated protein kinase mediates sevofluraneinduced cardioprotection. Circulation 2009, 120:S10-S15.

130. Bose AK, Mocanu MM, Carr RD, Brand CL, Yellon DM: Glucagon-like peptide 1 can directly protect the heart against ischemia/reperfusion injury. Diabetes 2005, 54:146-151.

131. Sonne DP, Engstrom T, Treiman M: Protective effects of GLP-1 analogues exendin-4 and GLP-1(9-36) amide against ischemia-reperfusion injury in rat heart. Regul Pept 2008, 146:243-249.

132. Timmers $L$, Henriques JP, de Kleijn DP, Devries JH, Kemperman $H$, Steendijk P, Verlaan CW, Kerver M, Piek JJ, Doevendans PA, Pasterkamp G, Hoefer IE: 
Exenatide reduces infarct size and improves cardiac function in a porcine model of ischemia and reperfusion injury. J Am Coll Cardio/ 2009, 53:501-510

133. Noyan-Ashraf MH, Momen MA, Ban K, Sadi AM, Zhou YQ, Riazi AM, Baggio LL, Henkelman RM, Husain M, Drucker DJ: GLP-1R agonist liraglutide activates cytoprotective pathways and improves outcomes after experimental myocardial infarction in mice. Diabetes 2009, 58:975-983.

134. Kristensen J, Mortensen UM, Schmidt M, Nielsen PH, Nielsen TT, Maeng M: Lack of cardioprotection from subcutaneously and preischemic administered liraglutide in a closed chest porcine ischemia reperfusion model. BMC Cardiovasc Disord 2009, 9:31.

135. Sauve M, Ban K, Momen MA, Zhou YQ, Henkelman RM, Husain M, Drucker DJ: Genetic deletion or pharmacological inhibition of dipeptidyl peptidase-4 improves cardiovascular outcomes after myocardial infarction in mice. Diabetes 2010, 59:1063-1073.

136. Ravassa S, Zudaire A, Diez J: GLP-1 and cardioprotection: from bench to bedside. Cardiovasc Res 2012, 94:316-323.

137. Ban K, Noyan-Ashraf MH, Hoefer J, Bolz SS, Drucker DJ, Husain M: Cardioprotective and vasodilatory actions of glucagon-like peptide 1 receptor are mediated through both glucagon-like peptide 1 receptordependent and -independent pathways. Circulation 2008, 117:2340-2350.

138. Zhao T, Parikh P, Bhashyam S, Bolukoglu H, Poornima I, Shen YT, Shannon RP: Direct effects of glucagon-like peptide-1 on myocardial contractility and glucose uptake in normal and postischemic isolated rat hearts. J Pharmacol Exp Ther 2006, 317:1106-1113.

139. Poornima I, Brown SB, Bhashyam S, Parikh P, Bolukoglu H, Shannon RP: Chronic glucagon-like-peptide-1 infusion sustains left ventricular systolic function and prolongs survival in the spontaneosly hypertensive, heart failure prone rat. Circ Heart Fail 2008, 1:153-160.

140. Wang D, Luo P, Wang Y, Li W, Wang C, Sun D, Zhang R, Su T, Ma X, Zeng C, Wang H, Ren J, Cao F: Glucagon-Like Peptide-1 Protects Against Cardiac Microvascular Injury in Diabetes Via a cAMP/PKA/Rho-Dependent Mechanism. Diabetes 2013. ePub ahead of print.

141. Vyas AK, Yang KC, Woo D, Tzekov A, Kovacs A, Jay PY, Hruz PW: Exenatide improves glucose homeostasis and prolongs survival in a murine model of dilated cardiomyopathy. PLoS One 2011, 6:e17178.

142. Gejl M, Sondergaard HM, Stecher C, Bibby BM, Moller N, Botker HE, Hansen SB, Gjedde A, Rungby J, Brock B: Exenatide alters myocardial glucose transport and uptake depending on insulin resistance and increases myocardial blood flow in patients with type 2 diabetes. $J$ Clin Endocrinol Metab 2012, 97:E1165-E1169.

143. Kawano T, Tanaka K, Chi H, Eguchi S, Yamazaki F, Kitamura S, Kumagai N, Yokoyama M: Biophysical and pharmacological properties of glucagonlike peptide- 1 in rats under isoflurane anesthesia. Anesth Analg 2012, 115:62-69.

144. Lloyd-Jones DM, Hong Y, Labarthe D, Mozaffarian D, Appel L, Van HL, Greenlund K, Daniels S, Nichol G, Tomaselli GF, Arnett DK, Fonarow GC, Ho PM, Lauer MS, Masoudi FA, Robertson RM, Roger V, Schwamm LH, Sorlie P, Yancy CW, Rosamond WD: Defining and setting national goals for cardiovascular health promotion and disease reduction: the American Heart Association's strategic Impact Goal through 2020 and beyond. Circulation 2010, 121:586-613.

145. Hill JO, Dorton J, Sykes MN, DiGirolamo M: Reversal of dietary obesity is influenced by its duration and severity. Int J Obes 1989, 13:711-722.

146. Bartness TJ, Polk DR, McGriff WR, Youngstrom TG, DiGirolamo M: Reversal of high-fat diet-induced obesity in female rats. Am J Physiol 1992, 263:R790-R797.

147. Davidoff AJ, Mason MM, Davidson MB, Carmody MW, Hintz KK, Wold LE, Podolin DA, Ren J: Sucrose-induced cardiomyocyte dysfunction is both preventable and reversible with clinically relevant treatments. Am J Physiol Endocrinol Metab 2004, 286:E718-E724.

148. Llado I, Proenza AM, Serra F, Palou A, Pons A: Dietary-induced permanent changes in brown and white adipose tissue composition in rats. Int J Obes 1991, 15:415-419.

149. Szilvassy Z, Ferdinandy P, Szilvassy J, Nagy I, Karcsu S, Lonovics J, Dux L, Koltai $M$ : The loss of pacing-induced preconditioning in atherosclerotic rabbits: role of hypercholesterolaemia. J Mol Cell Cardiol 1995, 27:2559-2569.

150. Shinmura K, Tamaki K, Bolli R: Short-term caloric restriction improves ischemic tolerance independent of opening of ATP-sensitive $\mathrm{K}+$ channels in both young and aged hearts. J Mol Cell Cardiol 2005, 39:285-296.
151. Hamdy O, Goodyear LJ, Horton ES: Diet and exercise in type 2 diabetes mellitus. Endocrinol Metab Clin North Am 2001, 30:883-907.

152. Veiga EC, Antonio EL, Bocalini DS, Murad N, Abreu LC, Tucci PJ, Sato MA: Prior exercise training does not prevent acute cardiac alterations after myocardial infarction in female rats. Clinics (Sao Paulo) 2011, 66:889-893.

153. Burelle Y, Wambolt RB, Grist M, Parsons HL, Chow JC, Antler C, Bonen A Keller A, Dunaway GA, Popov KM, Hochachka PW, Allard MF: Regular exercise is associated with a protective metabolic phenotype in the rat heart. Am J Physiol Heart Circ Physiol 2004, 287:H1055-H1063.

154. McElroy $C L$, Gissen SA, Fishbein MC: Exercise-induced reduction in myocardial infarct size after coronary artery occlusion in the rat. Circulation 1978, 57:958-962.

155. Freimann S, Scheinowitz M, Yekutieli D, Feinberg MS, Eldar M, KesslerIcekson G: Prior exercise training improves the outcome of acute myocardial infarction in the rat. Heart structure, function, and gene expression. J Am Coll Cardiol 2005, 45:931-938.

doi:10.1186/1475-2840-12-42

Cite this article as: van den Brom et al: Diabetes, perioperative ischaemia and volatile anaesthetics: consequences of derangements in myocardial substrate metabolism. Cardiovascular Diabetology 2013 12:42.

\section{Submit your next manuscript to BioMed Central and take full advantage of:}

- Convenient online submission

- Thorough peer review

- No space constraints or color figure charges

- Immediate publication on acceptance

- Inclusion in PubMed, CAS, Scopus and Google Scholar

- Research which is freely available for redistribution

Submit your manuscript at www.biomedcentral.com/submit
C BioMed Central 